\title{
MEASUREMENT OF SMALL QUANTITIES OF INSULIN-LIKE ACTIVITY WITH RAT ADIPOSE TISSUE. III. PERSISTENCE OF SERUM INSULIN-LIKE ACTIVITY AFTER PANCREATECTOMY*
}

\author{
BY JURGEN STEINKE, $\dagger$ ANNA SIREK, VILMA LAURIS, FRANCIS D. W. LUKENS \\ AND ALBERT E. RENOLD WITH THE TECHNICAL ASSISTANCE OF MARTA \\ GRINBERGS AND YANA HANUS \\ (From the Baker Clinic Research Laboratory in the Department of Medicine, Harvard Medi- \\ cal School, Boston, Mass., the Banting and Best Department of Medical Research, \\ University of Toronto, Canada, and the George S. Cox Medical Research \\ Institute, University of Pennsylvania, Philadelphia)
}

(Submitted for publication February 1, 1962; accepted May 17, 1962)

A bioassay procedure for small quantities of insulin, or insulin-like activity (ILA), ${ }^{1}$ using rat epididymal adipose tissue incubated in vitro, has been developed $(1,2)$ and its performance tested (3). In the course of the application of this procedure to blood serum, Leonards (4), as well as Goldberg and Egdahl (5), noted persistence of ILA after total pancreatectomy in dogs. This contrasted with the disappearance of insulin activity measured with the rat hemidiaphragm after pancreatectomy in dogs, as first reported by Groen, Kamminga, Willebrands and Blickman (6). Since it has become apparent that adipose tissue is an important site of metabolic activity $(7,8)$ and is peculiarly sensitive to a number of hormonal agents, investigation of the nature of the ILA in sera of pancreatectomized animals became of interest.

Our own studies were initially performed with sera from pancreatectomized cats, but the difficulty in obtaining serial blood samples of sufficient volume led to the use of dogs. In dogs, serial determinations of glucose and ketone bodies could be carried out, as well as measurements of ILA with rat adipose tissue and, in some instances, with the rat hemidiaphragm. The distribution of ILA within protein fractions was determined by column electrophoresis. The effect of incubation with reduced glutathione was investigated, and the ILA

* Supported in part by a grant-in-aid from the Lilly Research Laboratories and from the Hoechst Pharmaceuticals of Canada.

$\dagger$ Research Fellow of the American Diabetes Association.

1 The term ILA, as used in this report, always refers to activity on adipose tissue measured by the oxidation of glucose-1-C ${ }^{14}$ to $\mathrm{C}^{14} \mathrm{O}_{2}$. Insulin activity on other tissues, or on other indices of metabolism, will be qualified in each instance. was also measured after exposure of whole serum and its acid ethanol extract to anti-insulin serum.

The results strongly suggest that the persistence of ILA in sera of pancreatectomized dogs was associated with detectable amounts of insulin which did not exhibit biologic activity while circulating in vivo.

\section{MATERIAL AND METHODS}

The surgical procedures in cats were performed in Philadelphia (F.D.W.L.), those in dogs in Toronto (A.S.); the serum samples were analyzed in Boston (J.S., V.L., and A.E.R.).

Pancreatectomies in cats were performed under pentobarbital anesthesia, and the removal of the pancreas was judged to be complete when the amount of glucose excreted in the urine during the postoperative fasting state exceeded $2.5 \mathrm{~g}$ per $\mathrm{kg}$ per day and when autopsy showed a fatty liver and no residual pancreatic tissue (9). In pancreatectomized-hypophysectomized (Houssay) cats the usual reduction in glycosuria and absence of ketonuria were observed, and no residual pituitary tissue was found at autopsy. Serum prepared as described below was stored and shipped frozen.

Five mongrel dogs weighing between 10 and $15 \mathrm{~kg}$ were selected for this study. The pancreatectomies were performed under pentobarbital anesthesia. During the operation blood loss was kept to a minimum by atraumatic ligation of minute vessels (10). After surgery all dogs received penicillin by intramuscular injection for 5 days, but no insulin was ever administered. From the first postoperative day four of the dogs consumed measured amounts of commercial dog food supplemented by raw pancrease; the fifth dog did not eat until the third day after the operation. The record of food intake indicated a progressive decrease in appetite. No pancreatic remnants or visible ectopic pancreatic tissue were found in any of the dogs at autopsy. It is recognized that this conventional way of checking the completeness of the pancreatectomy and searching for an ectopic pancreas is not completely reliable. Nevertheless, we have abstained from intravital staining of the pancreatic islets with 
dithizone (11) because we did not want to shorten the lives of the animals by injecting a toxic substance and, moreover, the presence of an ectopic pancrease in the dog is a rarity (12). All five dogs had serial blood specimens drawn from the foreleg vein before, during, and after surgery. Preoperative control samples were obtained 3 hours after food and shortly before anesthesia. Postoperative blood was collected immediately after removal of the pancreas, then once daily. In three dogs the last blood sample was taken either at death or within $20 \mathrm{~min}$ utes after death. The remaining two dogs were found several hours after death had occurred and, therefore, the last available samples dated from the preceding day. Heparinized whole blood was used for glucose determinations. For ILA and other studies the blood was allowed to clot at room temperature and centrifuged; the serum was stored in the frozen state. In a few instances sera were pooled and care was taken to insure equal representation of the specimens. In all instances the serum samples were packed with sufficient dry ife and shipped to Boston by air. All samples were received frozen and were kept at $-20^{\circ} \mathrm{C}$ up to the time of their analysis. That prolonged storage in a frozen state does not significantly affect serum ILA has been established in this laboratory by a series of experiments extending over a period of 30 months; aliquots of large serum specimens have been assayed repeatedly (as many as 9 times) without significant change in serum ILA.

The glucose concentration in cat serum was determined by the Somogyi-Nelson technique $(13,14)$; the micromethod of King was employed in the dog (15). Ketone bodies were measured as acetone according to the technique of Greenberg and Lester, as modified by Boshell, Zahnd and Renold (16).

Serum ILA was determined in all samples with rat epididymal adipose tissue, with the oxidation of glucose-1$\mathrm{C}^{14}$ to $\mathrm{C}^{14} \mathrm{O}_{2}$ as index of activity $(2,3)$. The results were expressed as microunits per milliliter, and beef crystalline insulin in appropriate dilutions served as a standard. The index of precision (lambda) was calculated for each assay; those with a value for lambda greater than 0.30 were rejected. Groups of assays were evaluated for significance by standard statistics and 95 per cent confidence limits were calculated for single assays (3).

When incorporation of the glucose carbon into fatty acid or glycogen was taken as index of ILA, incubation was carried out for 3 hours with glucose-U-C ${ }^{14}$. Determinations of fatty acid and glycogen were carried out as previously described $(17,18)$. Fatty acid was directly assayed for radioactivity and glycogen was processed to glucosazone. Results were expressed as counts per minute per milligram adipose tissue. The activity of serum was compared with that of insulin standards by using the same "balanced segment design" as for ILA measurements by oxidation of glucose-1-C $\mathrm{C}^{14}(3)$.

The responsiveness of the diaphragm and of adipose tissue to a given sample was compared on the basis of glucose uptake by both tissues obtained from the same rat. Fasting animals weighing between 120 and $140 \mathrm{~g}$ served as donors. Glucose uptake by the diaphragm was measured according to Randle (19), Krebs-Ringer bicarbonate buffer being substituted for Gey and Gey buffer. The technique described by Martin, Renold and Dagenais (1) for measuring glucose uptake of the epididymal adipose tissue was modified and made comparable to the diaphragm assay. Single pads were incubated in toto instead of being cut into segments. The volume of the incubation medium was $1 \mathrm{ml}$; the concentration of glucose was adjusted either to $250 \mathrm{mg}$ per $100 \mathrm{ml}$ or to the highest value of serum glucose. Incubation time was 2 hours. Glucose was determined by the Somogyi-Nelson method (13). Results were expressed as milligrams of glucose taken up per gram of wet tissue per hour. In these experiments the insulin activity of serum was not assessed against the activity of crystalline beef insulin.

Column electrophoresis was carried out with the apparatus and the technique of Porath (20) as modified by Naughton and Taylor (21). Two $\mathrm{ml}$ of serum was applied, and the subfractions were collected and pooled into four fractions, favoring albumin, $\alpha-, \beta$-, and $\gamma$-globulins respectively. Each fraction was dialyzed against distilled water in the cold for $\mathbf{4 8}$ hours, lyophilized, and then dissolved in $8 \mathrm{ml}$ of Krebs-Ringer bicarbonate buffer with a glucose concentration of $250 \mathrm{mg}$ per $100 \mathrm{ml}$ for ILA assay with adipose tissue.

The preparation of acid ethanol extracts from sera was based on the technique described by Scott and Fisher (22) for insulin extraction from the pancreas. The extraction medium consisted of absolute ethanol $750 \mathrm{ml}$, concentrated $\mathrm{HCl} 15 \mathrm{ml}$, and distilled water $235 \mathrm{ml}$; all procedures were performed in the cold. The proportions used were one part serum to four parts acid ethanol. The mixture was continuously stirred for a minimum of 12 hours and centrifuged at $10,000 \mathrm{rpm}$. The supernatant was removed and the sediment was re-extracted for 2 hours with an identical volume of acid ethanol and then centrifuged. The two supernatants were combined and the $\mathrm{pH}$ adjusted to 8.5 ; they were allowed to stand for 15 to 20 minutes, then centrifuged. The supernatant was divided into $10-\mathrm{ml}$ portions, and each portion was added to a mixture of $15 \mathrm{ml}$ absolute ethanol and $25 \mathrm{ml}$ ethyl ether. After an interval of at least 10 hours, the mixture was centrifuged at $2,000 \mathrm{rpm}$. The precipitate in each tube was dissolved in $10 \mathrm{ml}$ of water acidified to $\mathrm{pH} 2.5$ with $\mathrm{HCl}$. The solutions were combined and dialyzed in Visking tubing no. $23 / 32$ against distilled water for 6 to 9 hours, then lyophilized and dissolved in Krebs-Ringer bicarbonate buffer containing $250 \mathrm{mg}$ glucose per $100 \mathrm{ml}$ for ILA assay. When crystalline insulin, alone or added to serum, was processed in identical manner, recoveries ranged from 80 to 93 per cent. In the case of endogenous serum ILA, the largest detectable loss, ranging from 10 to 28 per cent, occurred during dialysis, while the loss during lyophilization was negligible. However, the true total loss of endogenous serum ILA is impossible to estimate, since the correct value for extractable insulin originally present in serum is not known.

Anti-insulin serum was prepared by injecting guinea pigs with ultralente pure beef insulin, supplied through 
TABLE I

Serum glucose, ketone bodies, and ILA of normal, depancreatized, and Houssay cats

\begin{tabular}{|c|c|c|c|c|c|c|}
\hline \multirow[b]{2}{*}{$\begin{array}{l}\text { Condition } \\
\text { of cat }\end{array}$} & \multirow[b]{2}{*}{ Postop. } & \multirow[b]{2}{*}{ Fasting } & \multirow[b]{2}{*}{$\begin{array}{c}\text { Blood } \\
\text { glucose }\end{array}$} & \multirow{2}{*}{$\begin{array}{l}\text { Serum } \\
\text { ketone } \\
\text { bodies }\end{array}$} & \multicolumn{2}{|c|}{ ILA of undiluted serum } \\
\hline & & & & & Estimate & $\begin{array}{l}95 \% \text { confidence } \\
\text { limits }\end{array}$ \\
\hline & days & hrs & \multicolumn{2}{|c|}{$m g / 100 \mathrm{ml}$} & \multicolumn{2}{|c|}{$\mu U / 100 \mathrm{ml}$} \\
\hline Normal & & 48 & 86 & 4.4 & 80 & $36-190$ \\
\hline Normal & & 48 & 120 & 4.8 & 146 & $70-300$ \\
\hline Normal & & 48 & $214^{*}$ & 8.2 & 146 & $70-300$ \\
\hline Normal & & 48 & $184^{*}$ & 6.7 & 140 & $67-290$ \\
\hline Normal & & 24 & 105 & & 42 & $20-88$ \\
\hline Normal & & 12 & 98 & 2.1 & 80 & $42-166$ \\
\hline Depanc. & 2 & 48 & 528 & & 338 & $147-1,008$ \\
\hline Depanc. & 2 & 48 & 456 & & 231 & $86-620$ \\
\hline Depanc. & 2 & 48 & 376 & 61.2 & 330 & $112-570$ \\
\hline Depanc. & 2 & 48 & 472 & 35.6 & 125 & $46-341$ \\
\hline Depanc. & 2 & 48 & 436 & 56.0 & 52 & $14-137$ \\
\hline Depanc. & 2 & 48 & 524 & 54.8 & 32 & $10-65$ \\
\hline Houssay & $t$ & 72 & 332 & 7.6 & 75 & 23-202 \\
\hline Houssay & $f$ & 72 & 568 & 7.5 & $<31$ & $6-77$ \\
\hline
\end{tabular}

* It is difficult to avoid agonal hyperglycemia even in well trained cats.

+8 days after hypophysectomy, 3 days af ter pancreatectomy.

$\ddagger 18$ days after hypophysectomy, 3 days after pancreatectomy.

the courtesy of Doctor Mary Root of the Lilly Laboratories. The dose of insulin varied between three and seven $U$, depending on the weight of the animal, and was administered subcutaneously without adjuvants twice a week for 2 weeks, followed by a booster injection 1 month later. Blood was drawn the following week by cardiac puncture. The potency of the individual anti-insulin serum was judged to be adequate when $0.2 \mathrm{ml}$ of undiluted anti-insulin serum inhibited the effect of at least $17 \mathrm{mU}$ of beef crystalline insulin measured by the adipose tissue technique. Sera with adequate potency were pooled.

\section{RESULTS}

Studies in cats. Serum samples were obtained at the time of death from each of six normal, six pancreatectomized, and two Houssay cats. Analyses were carried out for glucose, ketone bodies, and ILA. The results are presented in Table I. The ILA in sera of intact cats as well as of the animals 48 hours after pancreatectomy showed marked scattering and wide overlap. The serum from the two Houssay cats was obtained 72 hours after pancreatectomy. Although the serum from one of these animals exhibited ILA below the low (31 $\mu \mathrm{U}$ per $\mathrm{ml}$ ) insulin standard, the value did not differ significantly either from that of the other Houssay animal or from that of some animals 48 hours after pancreatectomy.

Studies in dogs. In all five dogs, pancreatectomy was followed by severe diabetes with ketoacidosis leading to death. Two dogs died on day
5 , one on day 7 , and the remaining two on day 8 after complete removal of the pancreas. At least nine blood samples were secured from each dog, three of which were preoperative control specimens. A total of fifty-one blood specimens was analyzed. Figure 1 summarizes the results in a graphic form, and the statistical significance of the changes in serum ILA by the adipose tissue technique is shown in Table II. The preoperative mean values ranged from 312 to $445 \mu \mathrm{U}$ per ml and the postoperative mean values ranged from 174 to $232 \mu \mathrm{U}$ per $\mathrm{ml}$, thus indicating a fall in ILA. There was no profound decrease immediately after removal of the pancreas, but a significant fall in serum ILA was seen 24 hours later in each dog. No further change in serum ILA was noted on subsequent days, although the animals gradually deteriorated. The data summarized in Figure 1 are limited to the first five postoperative days, since two dogs died on day 5 . Considerable serum ILA was also found in samples obtained on the sixth day (three dogs) and on the seventh as well as eighth day (two dogs) after pancreatectomy. There is no doubt, therefore, that a relatively high ILA persists for many days in totally depancreatized dogs.

It is conceivable that substances other than insulin contributed to the high ILA in the sera of our diabetic dogs. The high concentration of glucose cannot be held responsible, since the glucose 


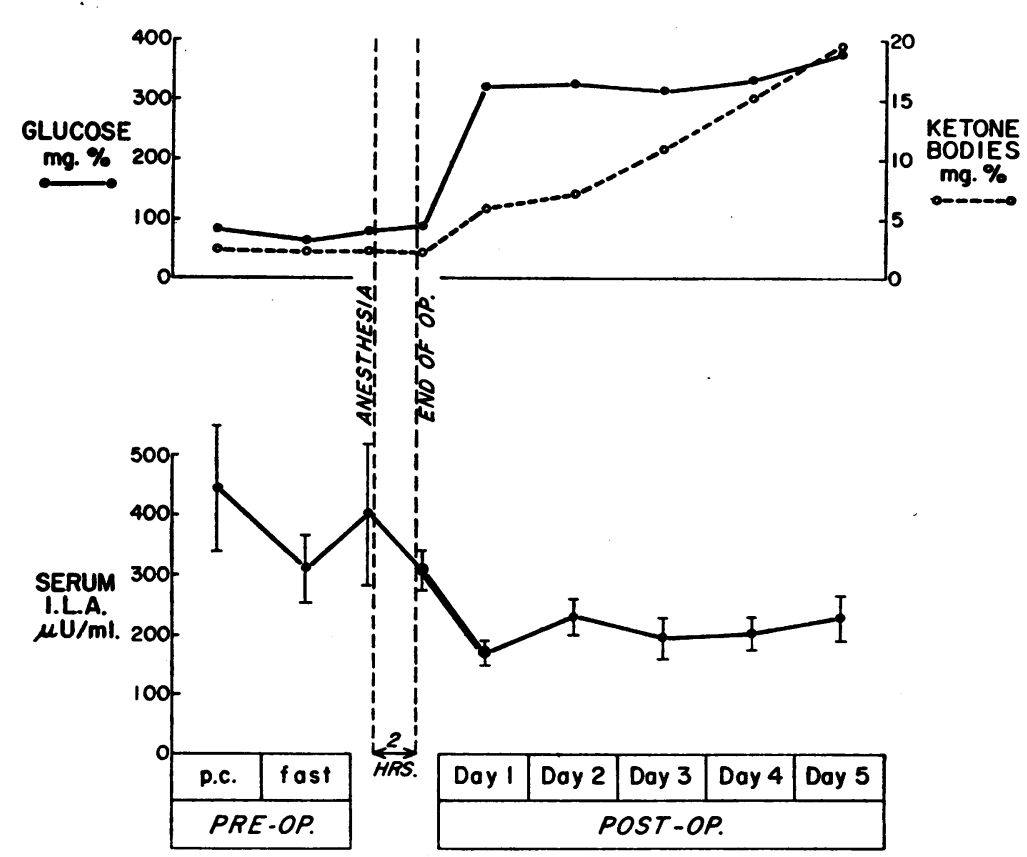

Fig. 1. EFfect of PANCREATECTOMY ON BLOOD GLUCOSE, SERUM Ketone BODIES, AND SERUM ILA IN FIVE DOGS.

concentration in the incubation media of insulin standards was kept at high levels, comparable to those of the sera. Ketone bodies, however, could have interfered with the assay, and this possibility was tested on a sample obtained on postoperative day 7 . One aliquot of the sample was dialyzed for 22 hours in the cold against buffer of identical glucose content; another portion of the same serum was not dialyzed but kept under refrigeration for the same length of time. The nondialyzed sample exhibited activity equivalent to
$190 \mu \mathrm{U}$ of insulin per $\mathrm{ml}$ (95 per cent confidence limits 130 to 285 ) as compared with $140 \mu \mathrm{U}$ per $\mathrm{ml}$ (95 per cent confidence limits 90 to 200) found in the dialyzed sample. This loss of serum ILA after dialysis is not statistically significant and is of the same order of magnitude as that observed after dialysis of normal human serum. It appears, therefore, that ketone bodies and other dialyzable substances did not appreciably influence serum ILA in this sample.

The incorporation of labeled glucose carbon into

TABLE II

Significance of differences between ILA of groups of sera reported in.Figure 1

\begin{tabular}{|c|c|c|c|c|}
\hline \multirow[b]{2}{*}{ Group } & \multirow[b]{2}{*}{ Description } & \multirow{2}{*}{$\begin{array}{l}\text { Number } \\
\text { of dogs }\end{array}$} & \multirow{2}{*}{$\begin{array}{l}\text { Number } \\
\text { of samples }\end{array}$} & Serum ILA \\
\hline & & & & Mean SE \\
\hline $\begin{array}{l}\mathrm{A} \\
\mathrm{B} \\
\mathrm{C} \\
\mathrm{D} \\
\mathrm{E}\end{array}$ & $\begin{array}{l}\text { All preoperative samples } \\
\text { Immediate preoperative } \\
\text { Immediate postoperative } \\
\text { One-day postoperative } \\
\text { All postoperative samples }\end{array}$ & $\begin{array}{l}5 \\
5 \\
5 \\
5 \\
5\end{array}$ & $\begin{array}{r}14 \\
5 \\
5 \\
5 \\
25\end{array}$ & $\begin{array}{l}\mu U / m l \\
383 \pm 52 \\
403 \pm 114 \\
310 \pm 32 \\
174 \pm 20 \\
208 \pm 13\end{array}$ \\
\hline $\begin{array}{l}\text { Probability } t \\
\text { E against } A \\
D \text { against A } \\
C \text { against } A \\
C \text { against } B \\
D \text { against } C\end{array}$ & $\begin{array}{l}\text { erence between groups is du } \\
\qquad \begin{array}{c}p<0.01 \\
p<0.01 \\
p>0.2 \\
p>0.3 \\
p<0.05\end{array}\end{array}$ & chance: & & \\
\hline
\end{tabular}


TABLE III

Effect of pooled dog serum, obtained 5 or more days after pancreatectomy, on the incorporation of uniformly labeled glucose carbon into fatty acid and glycogen of rat epididymal adipose tissue *

\begin{tabular}{lrc}
\hline \multicolumn{1}{c}{ Incubation medium } & Fatty acid & Glycogen \\
\hline & $c p m / m g$ & $c p m / m g$ \\
Buffer & $0.99 \pm 0.07$ & $1.6 \pm 0.4$ \\
Buffer $+62 \mu \mathrm{U} / \mathrm{ml}$ insulin & $8.53 \pm 0.93$ & $54.0 \pm 10.2$ \\
Buffer $+500 \mu \mathrm{U} / \mathrm{ml}$ insulin & $19.33 \pm 3.45$ & $193.8 \pm 24.5$ \\
Postpancreatectomy serum & $5.33 \pm 0.66$ & $48.8 \pm 10.6$
\end{tabular}

* Results expressed as cpm incorporated into fatty acid or glycogen per mg wet weight adipose tissue. Mean of six experiments with standard errors.

fatty acid and glycogen of rat epididymal adipose tissue incubated with diabetic sera was studied, and the results are presented in Table III. It is evident that pooled postoperative serum ( 5 or more days after pancreatectomy) exhibited ILA significantly exceeding the baseline response, although the activity was not quite equivalent to that of $62 \mu \mathrm{U}$ of crystalline insulin per ml. Qualitatively, therefore, ILA persisted with regard to all indices of insulin activity, whereas quantitative differences appeared to be related to the nature of the metabolic index used.

The effect of incubation with reduced glutathione upon ILA of a diabetic serum representing a pool of specimens obtained 5 or more days after pancreatectomy was compared with the effect of reduced glutathione on crystalline beef insulin. The results are presented in Table IV, and it is evident that preincubation has reduced the activity of the pooled serum to values well below that of $31 \mu \mathrm{U}$ of insulin per ml. Reduced glutathione has greatly diminished but not abolished the activity of crystalline insulin, a phenomenon that has previ-

TABLE IV

Effect of reduced glutathione, $0.02 M$, on ILA of pooled dog serum obtained 5 or more days after pancreatectomy*

\begin{tabular}{lc}
\hline \multicolumn{2}{c}{ Treatment } \\
\hline \\
& $c p m / m g$ \\
& $3.08 \pm 0.25$ \\
Buffer $+31 \mu \mathrm{U} / \mathrm{ml}$ insulin & $10.08 \pm 0.98$ \\
Buffer $+500 \mu \mathrm{U} / \mathrm{ml}$ insulin & $4.56 \pm 0.49$ \\
Buffer $+500 \mu \mathrm{U} / \mathrm{ml}$ insulin + reduced glutathionet & $4.64 \pm 0.37$ \\
Buffer +reduced glutathionet & $\mathbf{6 . 4 3} \pm \mathbf{0 . 7 2}$ \\
Postpancreatectomy serum & \\
Postpancreatectomy serum +reduced glutathionet & $2.00 \pm 0.49$
\end{tabular}

* The values represent $\mathrm{cpm}$ incorporated into $\mathrm{CO}_{2} / \mathrm{mg}$ epididymal adipose tissue incubated with glucose-1-C 14 for 2 hours. Mean of six experiments with standard errors.

$\dagger$ Preincubation with glutathione was carried out at room temperature for 3 hours prior to the addition of adipose tissue. The flasks not containing glutathione were identically treated.
TABLE V

Effect of anti-insulin serum $(0.1 \mathrm{ml} / \mathrm{ml}$ incubation medium $)$ on (A) ILA of pooled dog serum obtained 5 or more days after pancreatectomy, (B) ILA of the acid ethanol extract of the same postpancreatectomy dog serum pool, and (C) ILA of acid ethanol extract of dog pancreas*

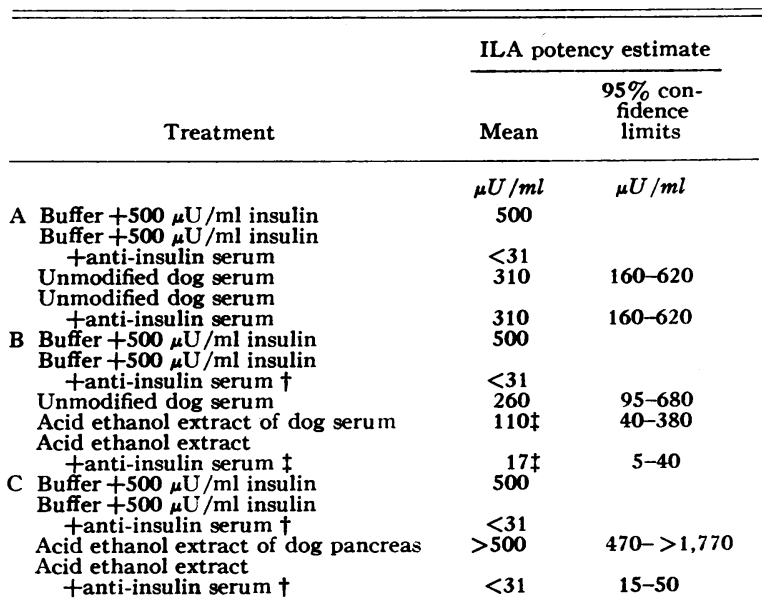

* Results expressed as $\mu \mathrm{U} / \mathrm{ml}$ by comparison with insulin standards. † Preincubation with anti-insulin serum was carried out at room temperature for 2 hours prior to the addition of adipose tissue. The lasks not containing anti-insulin serum were identically treated.

† Corrected to ILA equivalent of $1 \mathrm{ml}$ unmodified serum.

ously been commented upon (3) and is due to the intrinsic ILA of reduced glutathione in buffer, as also shown.

Table V contains the results of a series of observations concerning the effect of anti-insulin serum. This was prepared from guinea pigs as described above and inhibited effectively the activity of beef insulin standards and of acid ethanol extracts prepared from dog pancreas, but not the ILA of serum collected from all five dogs on or after postoperative day 5 and pooled in equal por-

TABLE VI

ILA of a preoperative and a postpancreatectomy (day 7) serum sample obtained from the same dog *

\begin{tabular}{|c|c|c|c|c|}
\hline \multirow[b]{3}{*}{ Sample } & \multicolumn{4}{|c|}{ ILA potency estimates } \\
\hline & \multicolumn{2}{|c|}{ Preoperative } & \multicolumn{2}{|c|}{ Postoperative } \\
\hline & Mean & $\begin{array}{l}\text { 95\% con- } \\
\text { fidence } \\
\text { limits }\end{array}$ & Mean & $\begin{array}{l}95 \% \text { con- } \\
\text { fidence } \\
\text { limits }\end{array}$ \\
\hline $\begin{array}{l}\text { A Unmodified serum } \\
\text { B Fraction I } \\
\text { Fraction II } \\
\text { Fraction III } \\
\text { Fraction IV } \\
\text { Sum I-IV }\end{array}$ & $\begin{array}{l}\mathbf{4 4 0} \\
270 \dagger \\
340 \\
540 \\
690 \\
1,840\end{array}$ & $\begin{array}{c}300-660 \\
160-470 \\
200-610 \\
330-1,010 \\
420-1,320 \\
1,110-2,410\end{array}$ & $\begin{array}{l}220 \\
130 \\
115 \\
120 \\
270 \\
635\end{array}$ & $\begin{array}{r}110-720 \\
95-180 \\
80-155 \\
85-160 \\
220-420 \\
480-915\end{array}$ \\
\hline
\end{tabular}

* The activity of unmodified serum is compared with that of 4 serum protein fractions prepared by column electrophoresis: predominantly albumin (I), $\alpha$-globulins (II), $\boldsymbol{\beta}$-globulins (III), and $\boldsymbol{\gamma}$-globulins (IV) Results expressed

$t$ Corrected to ILA equivalent of $1 \mathrm{ml}$ unmodified serum. 
tions. Of this pooled sample $100 \mathrm{ml}$ was extracted with acid ethanol. The extract exhibited activity on rat adipose tissue which was equivalent to about 40 per cent of that found in the native serum. Exposure to anti-insulin serum destroyed more than 80 per cent of the potency of this extract, thereby indicating that approximately onethird of the ILA originally present in the serum had been extracted and could now be inhibited by the addition of the anti-insulin serum.

The distribution of ILA among the protein fractions obtained by column electrophoresis was tested in one preoperative and one postoperative serum sample obtained from the same dog on day 7 after pancreatectomy. The results are presented in Table VI. The postoperative serum showed a significant decrease of ILA in each of the four fractions. There was no marked alteration of the pattern of distribution of ILA, although the postoperative decrease was perhaps most marked in fraction III. Contamination of fractions cannot be ruled out and also, in accordance with the finding of other authors (23-25), the sum of all fractions gave a considerably greater value than that obtained from the assay of unfractioned serum.

Results shown in Table VII demonstrate the effect of serum from a pancreatectomized dog upon glucose uptake by both the diaphragm and adipose tissue. Diluted serum had no detectable effect on either tissue, while undiluted serum exhibited significant ILA on adipose tissue but had no effect on the diaphragm. When an acid ethanol extract was prepared from the same serum, it was effective not only on adipose tissue but also on the diaphragmatic muscle. However, no data are available as to the effect of concentrated serum not prepared by acid ethanol extraction.

\section{DISCUSSION}

The persistence of ILA in sera of depancreatized dogs and cats measured on adipose tissue in vitro is in accord with similar reports of Leonards (4), Goldberg and Egdahl (5), and the most recent report of Slater, Samaan, Fraser and Stillman (26). Although a significant decrease was noted in all five dogs within 24 hours after complete removal of the pancreas, ILA remained measurable, and no further decline was detected up to the time of death which occurred between postoperative days 5 and 8. This persistence of ILA as measured with rat adipose tissue is in sharp contrast with the disappearance of ILA found with the rat hemidiaphragm. It has been reported from other laboratories that sera obtained from depancreatized cats (27), or depancreatized (6) and alloxanized (28) dogs gave no response with the latter type of assay. Vallance-Owen and Lukens (27) found in sera of pancreatectomized cats substances that antagonized the effect of insulin on the diaphragm. Whether or not such antagonists may account for the difference in results obtained by the two bioassays for our diabetic sera remains to be investigated.

The persistence of serum ILA on adipose tissue for several days after pancreatectomy can be in-

TABLE VII

Effect of pooled dog serum and of the acid ethanol extract of the same serum upon glucose uptake by rat hemidiaphragm and rat epididymal adipose tissue*

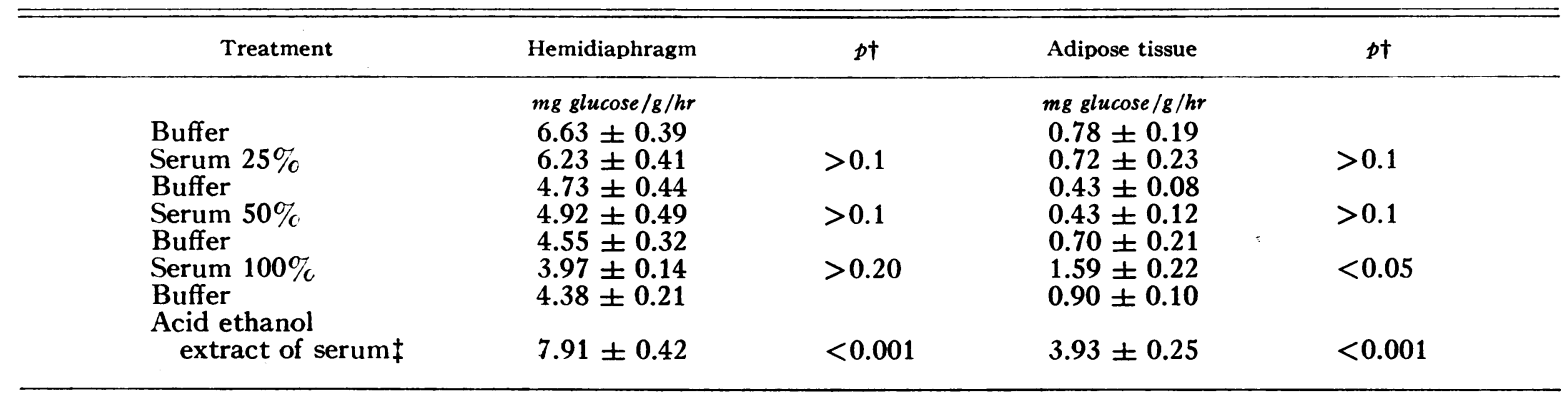

* The serum was obtained 5 or more days after pancreatectomy. Results expressed as mg glucose/g wet weight hemidiaphragm or adipose tissue per hour of incubation. In each instance the effect of serum was compared with that of buffer. The tissues of 8 rats were used for each experiment.

$\dagger$ Significance of serum effect compared to buffer alone, calculated according to Student's $t$ test.

$\ddagger$ Equivalent to 3.3-fold concentrate of serum. 
terpreted in two ways: Either the assay procedure is capable of measuring a form of insulin that is very slowly metabolized and essentially unavailable to the animal but available to adipose tissue in vitro, or the assay detects substances in serum that are not related to insulin at all. The results of our study support the former possibility because of the many similarities in behavior between insulin and the ILA of our diabetic sera. The ILA was nondialyzable and stimulated not only the oxidation of glucose, but also the incorporation of glucose carbon into glycogen and fatty acid of adipose tissue, although to a lesser extent. The ILA was abolished by treatment with reduced glutathione and, finally, a potent acid alcohol extract could be prepared from these sera. The only test in which the ILA persisting in sera of pancreatectomized animals did not resemble insulin was in its exposure to anti-insulin serum. This procedure failed to suppress the ILA of our diabetic sera.

A lack of significant suppression of serum ILA on adipose tissue by anti-insulin serum cannot be regarded as crucial, since a major portion of the ILA in sera of normal animals, such as dogs and cows, and also of the ILA of normal human sera is not influenced by preincubation with anti-insulin serum $(3,4,29)$. Acid alcohol extracts from sera of some nondiabetic and untreated diabetic subjects, however, do lose ILA after exposure to anti-insulin serum (30). Furthermore, insulinlike activity of some resin extracts prepared from beef pancreas remains unaffected by incubation with antiserum, but the same extracts become sensitive to antiserum when treated with acid alcohol (31). Thus, the finding that the ILA of an acid ethanol extract from pooled sera of depancreatized dogs was abolished after exposure to anti-insulin serum, while the native serum remained unaffected, is in keeping with other experimental evidence. The fact that Slater, Samaan, Fraser and Stillman (26) observed little effect of anti-insulin serum on the ILA of acid ethanol extracts of normal dog serum may be because in their procedure. serum was exposed to acid ethanol for a much shorter time (Slater, personal communication).

It is now generally recognized that anti-insulin serum obtained from guinea pigs immunized with beef insulin does not serve to identify a specific molecule with insulin activity; the antiserum reacts with insulins exhibiting considerable struc- tural differences (32-36). The possibility exists that the reaction may occur with insulin metabolites, precursors, or even with inactive variants of the molecule. Conversely, there may well be active variants of the molecule that fail to react with the antiserum, either because of intrinsic structural variation, or because of interference with the antigen-antibody reaction by prior association with other molecules. Thus, the insulin present in sera of our depancreatized animals may have been in a form that either was nonreactive in the antigenantibody reaction, or that reacted but retained biologic activity. Extraction with acid alcohol may have changed the molecule in such a way as to enhance or modify its ability to react with the antiserum. The possibility that structural changes occurred in the insulin molecule or in its association with other molecules during acid alcohol extraction is further strengthened by the significant insulin activity of the extract on the diaphragm as compared with the ineffectiveness of the native serum (Table VII). The observation of Yalow and Berson, as reported by Goldberg and Egdahl (5), that serum from pancreatectomized dogs does not contain immunologically demonstrable insulin does not conflict with the ideas outlined above.

A similar situation is encountered with the sera of untreated juvenile diabetics. Sera from these patients exhibit considerable ILA on exposure to rat adipose tissue (37), but little or none on exposure to diaphragm $(38,39)$. The ILA on the latter tissue can be unmasked by electrophoretic fractionation of serum proteins (23-25) or by extraction with acid ethanol (unpublished observations). Because of the lack of precise knowledge concerning the chemical or physicochemical state of insulin in normal and diabetic sera, it is impossible to reach any definite conclusions at this time. On the basis of our results the following hypothesis has been formulated. Removal of the pancreas in the dog causes a relatively rapid (24 hours or less) disappearance of that portion of serum ILA that is available to all insulin-dependent tissues of the animal and that affects both the isolated rat diaphragm and rat adipose tissue. After this initial decrease, the remaining serum ILA of the diabetic animal appears to consist, at least in part, of a fraction that is very slowly metabolized, is unavailable to the tissues of the living animal and to the isolated rat diaphragm, 
but is still available to the isolated normal rat adipose tissue. After extraction with acid ethanol, however, some effectiveness on the rat diaphragm is unmasked, and partial neutralization by antiinsulin can be shown. The evidence is in favor of a form of insulin that affects adipose tissue in vitro but is otherwise a biologically inactive modification of the hormone. This hypothesis implies that the serum insulin pool is not homogeneous, as had already been shown for the circulating insulin bound to antibodies in patients treated with exogenous insulin for a prolonged period (40).

Two limitations of these observations must be pointed out. First, the slowly metabolized ILA fraction described here may have been released from the pancreas during surgery, and its presence in serum may thus be artifactual. Second, the presence of serum ILA, which persisted after pancreatectomy and which could be extracted with acid ethanol and inhibited by the addition of antiinsulin serum, accounted for only one-third of the total postpancreatectomy serum ILA. Although this may be due to incomplete extraction, the nature of the remaining two-thirds of this activity must, for the present, remain conjectural.

\section{SUM MARY}

1. Serum insulin-like activity (ILA), as measured on glucose oxidation by adipose tissue in vitro, persisted in significant amounts for 2 days after total pancreatectomy in cats, and for up to 8 days after total pancreatectomy in dogs. This contrasts with the known disappearance of insulin activity, as measured on the rat hemidiaphragm, in samples of postpancreatectomy serum.

2. In five dogs, serum ILA was measured daily after pancreatectomy, until death occurred between 5 and 8 days. A significant decrease to about onehalf the preoperative level occurred within 20 hours postoperatively, but no further decline was detected up to the time of death.

3. ILA of postpancreatectomy dog serum resembled insulin in that it was nondialyzable; it stimulated not only the oxidation of glucose but also, to a lesser extent, the incorporation of glucose carbon into glycogen and fatty acid of adipose tissue; it was totally abolished by exposure to reduced glutathione; and it could in part be extracted from postpancreatectomy serum with acid ethanol.
4. ILA of postpancreatectomy dog serum did not resemble insulin in that anti-insulin serum failed to suppress it. However, anti-insulin serum did suppress significantly the ILA of an acid ethanol extract of postpancreatectomy dog serum. Acid ethanol extracts of postpancreatectomy serum also exhibited significant insulin activity on glucose uptake by rat hemidiaphragm.

5. These results strongly suggest that the persistence of ILA in serum of pancreatectomized dogs is associated with detectable amounts of insulin or of a substance closely resembling insulin, although characterized by a long intravascular half life and by absence of biologic activity while circulating in vivo.

\section{REFERENCES}

1. Martin, D. B., Renold, A. E., and Dagenais, Y. M. An assay for insulin-like activity using rat adipose tissue. Lancet 1958, 2, 76.

2. Renold, A. E., Martin, D. B., Dagenais, Y. M., Steinke, J., Nickerson, R. J., and Sheps, M. C. Measurement of small quantities of insulin-like activity using rat adipose tissue. I. A proposed procedure. J. clin. Invest. 1960, 39, 1487.

3. Sheps, M. C., Nickerson, R. J., Dagenais, Y. M., Steinke, J., Martin, D. B., and Renold, A. E. Measurement of small quantities of insulin-like activity using rat adipose tissue. II. Evaluation of performance. J. clin. Invest. 1960, 39, 1499.

4. Leonards, J. R. Insulin-like activity of blood, what is it? Fed. Proc. 1959, 18, 272.

5. Goldberg, H. L., and Egdahl, R. H. Studies suggesting the extra-pancreatic production of substances with insulin-like activity. Fed. Proc. 1961, 20, 190.

6. Groen, J., Kamminga, C. E., Willebrands, A. F., and Blickman, J. R. Evidence for the presence of insulin in blood serum. A method for an approximate determination of the insulin content of blood. J. clin. Invest. 1952, 31, 97.

7. Wertheimer, E., and Shafrir, E. Influence of hormones on adipose tissue as a center of fat metabolism. Recent Progr. Hormone Res. 1960, 16, 467.

8. Jeanrenaud, B. Dynamic aspects of adipose tissue metabolism: a review. Metabolism 1961, 10, 535.

9. Gordon, M. F., Buse, J. F., and Lukens, F. D. W. Hypoglycemic sulfonylureas in various types of experimental diabetes. Diabetes 1957, 6, 7-12.

10. Sirek, A. A hook-like instrument for atraumatic ligation of minute vessels. Proc. Soc. exp. Biol. (N. Y.) 1957, 94, 526.

11. Maske, $H$. Interaction between insulin and zinc in the islets of Langerhans. Diabetes 1957, 6, 335.

12. Barron, C. N. Ectopic pancreas in the dog, a report of three cases. Acta anat. 1959, 36, 344. 
13. Nelson, N. A photometric adaptation of the Somogyi method for the determination of glucose. J. biol. Chem. 1944, 153, 375.

14. Somogyi, M. Determination of blood sugar. J. biol. Chem. 1945, 160, 69.

15. King, E. J. Micro-analysis in Medical Biochemistry, 2nd ed. London, J. \& A. Churchill, 1951, p. 23.

16. Boshell, B. R., Zahnd, G. R., and Renold, A. E. An effect of tolbutamide on ketogenesis, in vivo and in vitro. Metabolism 1960, 9, 21.

17. Cahill, G. F., Jr., Leboeuf, B., and Renold, A. E. Studies on rat adipose tissue in vitro. III. Synthesis of glycogen and glyceride-glycerol. J. biol. Chem. 1959, 234, 2540.

18. Bally, P., Cahill, G. F., Jr., Leboeuf, B., and Renold, A. E. Studies on rat adipose tissue in vitro. V. Effects of glucose and insulin on the metabolism of palmitate-1-C ${ }^{14}$. J. biol. Chem. 1960, 235, 333.

19. Randle, P. J. Assay of plasma insulin activity by the rat-diaphragm method. Brit. med. J. 1954, 1, 1237.

20. Porath, J. Methodological studies of zone-electrophoresis in vertical columns. I. Fractionation in cellulose powder columns of substances of low molecular weight exemplified by amino acids and related compounds. Biochim. biophys. Acta 1956, 22, 151.

21. Naughton, M. A., and Taylor, K. W. A method of continuous elution during column electrophoresis. Biochem. J. 1960, 77, 46.

22. Scott, D. A., and Fisher, A. M. The insulin and zinc content of normal and diabetic pancreas. J. clin. Invest. 1938, 17, 725.

23. Taylor, K. W. Serum insulin in a case of severe diabetes mellitus showing remission. Brit. med. J. 1960, 1, 1853.

24. Gundersen, K., and Williams, R. H. Insulin antagonism in serum of untreated diabetics and in previously treated diabetics with ketoacidosis. Proc Soc exp. Biol. (N. Y.) 1960, 105, 390.

25. Willebrands, A. F. Serum insulin and anti-insulin activity in diabetic acidosis. Clin. chim. acta 1960, 5, 508.

26. Slater, J. D. H., Samaan, N., Fraser, R., and Stillman, D. Immunological studies with circulating insulin. Brit. med. J. 1961, i, 1712.

27. Vallance-Owen, J., and Lukens, F. D. W. Studies on insulin antagonism in plasma. Endocrinology $1957,60,625$.
28. Takeuchi, S., Ohashi, S., and Kobayashi, Y. Quantitative assay of insulin in blood plasma in normal and alloxanized dogs by rat diaphragm method. J. Pharmacol. exp. Ther. 1957, 119, 436.

29. Renold, A. E., Steinke, J., and Antoniades, H. N. Insulin-like activity in human serum and pancreatic extracts, as measured with rat adipose tissue. Acta endocr. (supplementum 51) 1960, 35, 1235.

30. Steinke, J., Taylor, K. W., Gundersen, K., and Renold, A. E. Serum insulin-like activity of untreated patients with recent onset of diabetes mellitus. Fourth Congress of the International Diabetes Federation, Geneva 1961, 1, 632.

31. Antoniades, H. N., Renold, A. E., Dagenais, Y. M., and Steinke, J. Preliminary observations on state of insulin in human and bovine pancreas. Proc. Soc. exp. Biol. 1960, 103, 677.

32. Moloney, P. J., and Goldsmith, L. On the antigenicity of insulin. Canad. J. Biochem. 1957, 35, 79.

33. Berson, S. A., and Yalow, R. S. Species-specificity of human anti-beef, pork insulin serum. J. clin. Invest. 1959, 38, 2017.

34. Moloney, P. J., and Aprile, M. A. Neutralization of cod insulin with antiserum: precipitation of insulinanti-insulin complex with ethanol-water. Canad. J. Biochem. 1960, 38, 1216.

35. Berson, S. A., and Yalow, R. S. Immunochemical distinction between insulins with identical aminoacid sequences. Nature (Lond.) 1961, 191, 1392.

36. Yalow, R. S., and Berson, S. A. Immunologic aspects of insulin. Amer. J. Med. 1961, 31, 882.

37. Steinke, J., Camerini, R., Marble, A., and Renold, A. E. Elevated levels of serum insulin-like activity (ILA) as measured with adipose tissue in early untreated diabetes and prediabetes. Metabolism 1961, 10, 707.

38. Steinke, J., Taylor, K. W., and Renold, A. E. Insulin and insulin antagonists in the serum of untreated juvenile diabetes; studies with isolated rat diaphragm and rat adipose tissue. Lancet 1961, 1, 30.

39. Vallance-Owen, J., Hurlock, B., and Please, N. W. Plasma-insulin activity in diabetes mellitus measured by rat diaphragm technique. Lancet 1955, 2 , 583.

40. Berson, S. A., Yalow, R. S., Bauman, A., Rothschild, M. A., and Newerly, K. Insulin I-131 metabolism in human subjects : demonstration of insulin binding globulin in the circulation of insulin treated subjects. J. clin. Invest. 1956, 35, 170. 